\title{
Foraminifera from the Tepetate Formation (Heim) at Las Pocitas, Baja California Sur, Mexico
}

\section{Foraminíferos de la formación Tepetate (Heim) en el área de Las Pocitas, Baja California Sur, México}

\author{
AY Miranda-Martínez ${ }^{1}$, AL Carreño² \\ ${ }^{1}$ Posgrado en Ciencias de la Tierra, CICESE, Carretera Ensenada-Tijuana km 107, Ensenada, CP 22830, Baja California, \\ México. E-mail: amiranda@cicese.mx \\ 2 Instituto de Geología, Universidad Nacional Autónoma de México, Circuito Exterior, CU, Delegación Coyoacán, CP 04510 \\ DF, México.
}

\begin{abstract}
In order to constrain the age and depositional paleoenvironment of the Tepetate Formation, benthic and planktonic foraminifera were analyzed in samples recovered from an exploration well located at Las Pocitas, Baja California Sur, Mexico. The planktonic taxa identified allowed recognition of Zone P9 (Planorotalites palmerae-Acarinina pentacamerata), equivalent to a late early Eocene age of 50.4-49 Ma. The benthic foraminiferal association suggests that the sediments were deposited in a continental slope environment at an upper bathyal water depth of $c a$. $500 \mathrm{~m}$. Composition and diversity of planktonic foraminifera indicate the presence of warm-temperate surface water masses. Micropaleontological evidence presented here and from previous reports indicates that the samples studied represent only a portion of the Tepetate Formation.
\end{abstract}

Key words: Tepetate, Paleogene, Baja California, foraminifera.

\section{Resumen}

Con el propósito de contribuir a precisar la edad y el ambiente de depósito de la formación Tepetate, se analizó el conjunto de foraminíferos planctónicos y bentónicos presente en muestras de un núcleo procedente de un pozo perforado en la localidad de Las Pocitas, Baja California Sur, México. Los alcances estratigráficos de las especies planctónicas permitieron reconocer la Zona P9 (Planorotalites palmerae-Acarinina pentacamerata) correspondiente a la parte tardía del Eoceno temprano, entre 50.4 y $49 \mathrm{Ma}$. El conjunto de foraminíferos bentónicos sugiere que los sedimentos se depositaron en el talud continental a una profundidad de, por lo menos 500 m, entre el dominio del batial superior y medio superior. La composición y la diversidad de los foraminíferos planctónicos sugieren la presencia de masas de agua superficiales cálido-templadas. La evidencia micropaleontológica aquí presentada, y la de reportes previos, indican que las muestras estudiadas sólo representan una porción de la formación Tepetate.

Palabras clave: Tepetate, paleógeno, Baja California, foraminífero.

\section{Introduction}

The Tepetate lithostratigraphic unit includes the oldest Paleogene marine rocks exposed in Baja California Sur (BCS), Mexico, and clearly records aspects of the depositional and paleoceanographic history of the marginal eastern Pacific Ocean. Previous interpretations of this unit have suggested that the Tepetate Formation represents a variety of depositional environments and an age span from late Cretaceous (Fullwider 1976) to late Eocene (González-Barba 2002). The name Tepetate was first applied in 1922 prior to the publication of the North American Stratigraphic Code in 1961, and remains an informal designation.

The sedimentary rocks, today Tepetate Formation, were first described by Darton (1921) in exposures at Arroyo Salada and Arroyo Colorado, in the Rancho Tepetate area of BCS (fig. 1). Heim (1922) first applied the name Tepetate to designate marine rocks cropping out in Arroyo Colorado, near Rancho Tepetate. A second locality east of Santa Margarita

\section{Introducción}

La formación Tepetate representa el paquete de rocas marinas paleógenas más antiguas que afloran en Baja California Sur (BCS), registrando la historia deposicional y paleoceanográfica en la margen oriental del Pacífico. Interpretaciones previas de esta unidad han sugerido que la formación Tepetate representa una variedad de ambientes de depósito de edad Cretácico Tardío (Fullwider 1976) a Eoceno tardío (GonzálezBarba 2002). A pesar de ser una unidad ampliamente reconocida, la formación Tepetate es considerada como una unidad informal, debido a que fue descrita y nombrada antes de la publicación del Código Norteamericano de Estratigrafía en 1961 y subsecuentes.

La primera descripción de las rocas sedimentarias de este intervalo de tiempo fue realizada por Darton (1921), quien describe las rocas que afloran en los arroyos Salada y Colorado, en los alrededores de Rancho Tepetate, BCS (fig. 1). Heim (1922) emplea por primera vez el nombre de Tepetate para designar a 
Island and two localities close to Rancho San Hilario were also described by this author. The Tepetate Formation was originally described as a 1000-m-thick, neritic, light grey sandstone package of Eocene age. Structurally, Heim (1922) described it as slightly folded and resting unconformably below a 30.5-mthick sequence of well-stratified light grey sandstone and green to violet shale assigned to the Salada Formation. Beal (1948) recognized the Tepetate exposures at three localities along the Pacific coast of BCS: (1) an area east and southeast of Magdalena Bay, (2) an area from Punta San Isidro to the southeast of Punta Canoas, and (3) an area near the Santa Clara Desert; these last two areas were later considered by LozanoRomen (1975) to belong to the Sepultura and Bateque formations, respectively. Beal (1948) also established two sections through the Tepetate Formation, one in Arroyo Salada and another in rocks surrounding Rancho Tepetate, and interpreted both exposures to represent Eocene shallow-water, delta-type deposits. Mina-Uhink (1957) restricted the name Tepetate to those rocks exposed from Rancho Santa Rita to Arroyo El Conejo, and proposed the sedimentary column exposed in Arroyo Colorado as type locality of the formation. Mina-Uhink (1957) assigned a Paleocene to middle Eocene age to the Tepetate Formation and interpreted the entire unit as a neritic and locally deltaic deposit.

Knappe (1974) conducted the first micropaleontological study of the Tepetate Formation. This author studied foraminifera in samples from Arroyo Datilar and Arroyo El Conejo, and recognized the Morozovella formosa formosa, Morozovella aragonensis, Acarinina pentacamerata, and Hantkenina nuttalli zones of Bolli (1966). Knappe (1974) assigned an early middle Eocene age to the Tepetate Formation, equivalent to the Penutian and Ulatisian benthic

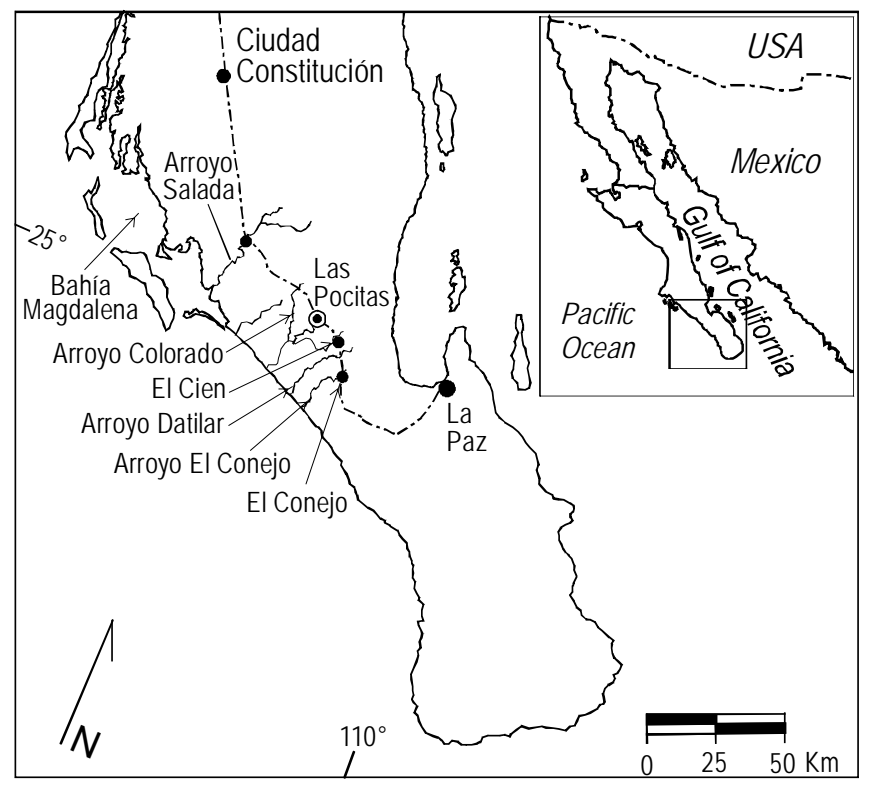

Figure 1. Location of the Las Pocitas core, Baja California Sur, Mexico. Figura 1. Localización del núcleo Las Pocitas, Baja California Sur, México. las rocas marinas que afloran en las cercanías del Rancho Tepetate, en el Arroyo Colorado, describiendo una segunda localidad al oriente de Isla Santa Margarita y dos más en las cercanías de Rancho San Hilario. La formación Tepetate fue originalmente descrita como un paquete de arenisca gris claro de $1000 \mathrm{~m}$ de espesor, depositada en un ambiente de plataforma. Estructuralmente Heim (1922) la describe ligeramente plegada y descansando discordantemente bajo $30.5 \mathrm{~m}$ de arenisca verde, arenisca gris claro bien estratificada, y lutita verde a violeta, pertenecientes a la formación Salada. Beal (1948) reconoce esta unidad en tres áreas a través de la costa del Pacífico de BCS incluyendo: (1) un área localizada al este y sudeste de Bahía Magdalena, (2) otra localizada desde Punta San Isidro al sudeste de Punta Canoas, (3) y una cerca del desierto de Santa Clara, éstas dos últimas consideradas más tarde por Lozano-Romen (1975) como pertenecientes a las formaciones Sepultura y Bateque, respectivamente. Beal (1948) establece dos secciones para la formación Tepetate, una en Arroyo Salada y la otra en los alrededores del Rancho Tepetate. En ambas secciones, este autor interpreta estos afloramientos como depósitos eocénicos de agua somera tipo deltaico. MinaUhink (1957) restringe el nombre de Tepetate a las rocas que afloran desde el Rancho Santa Rita hasta Arroyo El Conejo y propone la columna sedimentaria expuesta en Arroyo Colorado como localidad típica. Mina-Uhink (1957) asigna a la formación Tepetate una edad del Paleoceno al Eoceno medio y sugiere un depósito nerítico localmente deltaico para toda la unidad.

El primer estudio micropaleontológico en la formación Tepetate fue llevado a cabo por Knappe (1974) en rocas expuestas en los arroyos El Datilar y El Conejo. Este autor reconoce, con base en foraminíferos planctónicos y siguiendo el esquema zonal de Bolli (1966), las zonas Morozovella formosa formosa, Morozovella aragonensis, Acarinina pentacamerata y Hantkenina nuttalli. Knappe asigna a la formación Tepetate una edad correspondiente a la parte temprana del Eoceno medio, equivalente a los pisos clásicos del Penutiano y Ulatisiano descritos en California (Mallory 1959), y concluye que el conjunto de foraminíferos bentónicos presente en sus muestras sugiere un depósito en un ambiente del talud medio y superior.

El estudio micropaleontológico y litológico más completo de la formación Tepetate fue realizado por Fullwider (1976), quien analizando dos secciones localizadas en los arroyos Salada y Colorado reconoció las zonas de Morozovella trinidadensis, Globanomalina pseudomenardii, Morozovella velascoensis, Morozovella subbotinae, Morozovella formosa formosa, Morozovella aragonensis, Globigerinatheka senni y Acarinina pentacameratus del Paleoceno temprano al Eoceno temprano de Stainforth et al. (1975). Fullwider también identificó dos hiati representados por la ausencia de las zonas de Globorotalia pseudobulloides del Paleoceno temprano, y de Morozovella uncinata, Morozovella angulata y Morozovella pusilla pusilla, del Paleoceno medio. Debido a la presencia de nanoplancton calcáreo en una muestra recolectada en Arroyo 
foraminiferal stages of California (Mallory 1959), and concluded that benthic foraminifera in the samples represented an upper to middle slope assemblage.

The most complete micropaleontological and lithological study of the Tepetate Formation to date was made by Fullwider (1976), who analyzed samples from stratigraphic sections exposed in Arroyo Salada and Arroyo Colorado, and recognized the early Paleocene to early Eocene zones of Stainforth et al. (1975): Morozovella trinidadensis, Globanomalina pseudomenardii, Morozovella velascoensis, Morozovella subbotinae, Morozovella formosa formosa, Morozovella aragonensis, Globigerinatheka senni, and Acarinina pentacameratus. Fullwider (1976) identified two hiati within the formation based on the absence of the early Paleocene Globorotalia pseudobulloides zone and middle Paleocene Morozovella uncinata, Morozovella angulata, and Morozovella pusilla pusilla zones, and extended the range of the Tepetate Formation to the Upper Cretaceous (Maastrichtian) based on the presence of the calcareous nannoplankton Tetralithus nitidus Martin, Watznauria barnesae (Black), Watznauria biporta Bukry, and Arkhangeliskiella cymbiformia Velshira in a sample from Arroyo Salada. This author, based on lithological (cannonball, interbedded, and crossbedded informal members) and foraminiferal evidence, interpreted the Tepetate rocks to represent deposition in an upper slope setting, under low oxygen conditions, in a complex submarine fan subenvironment. Later, Coleman (1979), based on the calcareous nannoplankton assemblage recovered from the same samples, also gave Maastrichtian to early Eocene ages.

Pérez-Venzor and Carreño (1995) mapped and described the lithology of the Tepetate unit in the area of Las Pocitas in an unpublished report of the Autonomous University of Baja California Sur (UABCS). Several authors have studied sedimentary aspects (Vázquez-García and Schwennicke 1996) and the taxonomy of different groups, such as mollusks (Perrilliat 1996), ostracods and foraminifers (Guerrero-Arenas 1998). In a detailed biostratigraphic and geological work of the unit, Ledesma-Vázquez et al. (1999) and Carreño et al. (2000), describe contemporary deposits from the end of the early Eocene to the beginning of the middle Eocene (51.3 to 48.4 $\mathrm{Ma}$ ), suggesting a neritic storm deposit in Arroyo Colorado exposures, whereas to the west, the Las Pocitas rocks represent the distal facies of an upper bathyal submarine fan. In addition, these authors noted that the Arroyo Colorado exposures represent only a part of this lithostratigraphic unit, thus establishing that, contrary to that proposed by Mina-Uhink (1957), they cannot be considered the type section of the Tepetate Formation.

Recently, García-Cordero and Carreño (2008) identified a calcareous nannoplankton assemblage in the Tepetate samples studied here, which is characteristic of Okada and Bukry's (1980) Subzone CP12a (Discoasteroides kuepperi), recently considered of middle Eocene age by Gradstein and Ogg (2005). In view of these findings and of the abundance of foraminifera throughout the Las Pocitas core, this study was
Salada que incluye a Tetralithus nitidus Martin, Watznauria barnesae (Black), Watznauria biporta Bukry y Arkhangeliskiella cymbiformis Vekshira, Fullwider (1976) extendió el alcance estratigráfico de la formación Tepetate al Cretácico Superior (Maastrichtiano). Basado en el conjunto de foraminíferos y en la información litoestratigráfica (miembros cannonball, interbedded y crossbedded), este autor infiere una paleprofundidad batial media superior, bajo déficit de oxígeno en un subambiente de complejo de abanico submarino. Más tarde Coleman (1979), con base en las especies de nanoplancton calcáreo presentes en estas muestras, corrobora la edad maastrichtiana a eocénica temprana.

Pérez-Venzor y Carreño (1995) cartografiaron y describieron la unidad, particularmente en el área de Las Pocitas y sus alrededores; desfortunadamente el trabajo permanece inédito en la Universidad Autónoma de Baja California Sur (UABCS). Varios autores han estudiado puntualmente aspectos sedimentológicos (Vázquez-García y Schwennicke 1996), así como taxonómicos con grupos como moluscos (Perrilliat 1996); ostrácodos y foraminíferos (Guerrero-Arenas 1998). En un trabajo bioestratigráfico y geológico detallado de la unidad, Ledesma-Vázquez et al. (1999) y Carreño et al. (2000) describen depósitos contemporáneos de finales del Eoceno temprano a principios del Eoceno medio (51.3 a $48.4 \mathrm{Ma}$ ), sugiriendo un ambiente somero asociado a eventos de tormenta en afloramientos de Arroyo Colorado, mientras que al oeste, las rocas de Las Pocitas representan las facies distales de un abanico turbidítico en el batial superior.. Además, estos autores consideran que ambas secciones corresponden sólo a una parte de la unidad y, por tanto, en contra de lo propuesto por Mina-Uhink (1957), establecen que Arroyo Colorado no puede ser considerada como típica de la formación Tepetate.

Recientemente, García-Cordero y Carreño (2008) con base en nanoplancton calcáreo presente en el núcleo de Las Pocitas sólo pudieron reconocer, debido al retrabajo intenso de estos microfósiles, la subzona CP12a Discoasteroides kuepperi de Okada y Bukry (1980), recientemente considerada por Gradstein y Ogg (2005) como del Eoceno medio. Por ello, y debido a la abundancia de foraminíferos a lo largo del núcleo Las Pocitas, este estudio se realizó con la intención de proveer evidencia micropaleontológica sobre la edad y la historia deposicional de la formación Tepetate, coadyuvando al conocimiento de esta unidad y aportando elementos que podrían ser empleados en la redescripción formal de ésta.

\section{Material y método}

Las rocas sedimentarias de la formación Tepetate provienen de un núcleo perforado en los alrededores del poblado de Las Pocitas, localizado aproximadamente $76 \mathrm{~km}$ al sur de Ciudad Constitución, en el Municipio de La Paz, BCS (UNAM Loc. 2984; 24⒉ $4^{\prime} 00^{\prime \prime} \mathrm{N}, 111^{\circ} 05^{\prime} 47^{\prime \prime}$ W, Carta Las Pocitas, Baja California Sur, México, 1:50,000, G12C79, CGSINEGI 1983; fig. 1). La perforación de $80 \mathrm{~m}$ fue realizada por la Secretaría, 
undertaken to provide micropaleontological evidence for the age and depositional history of the Tepetate Formation, thus contributing to the understanding of the unit and supplying useful data for its formal redescription.

\section{Material and methods}

The sedimentary rock samples of the Tepetate Formation were recovered from a core of a well drilled near Las Pocitas, located approximately $76 \mathrm{~km}$ south of Ciudad Constitución,

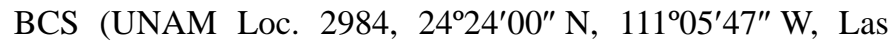
Pocitas Quadrangle, Baja California Sur, Mexico, 1:50,000, G12C79, CGSINEGI 1983; fig. 1). The well was drilled by the Ministry of Hydraulic Resources and reached a depth of $80 \mathrm{~m}$. Drilling recovered $62 \mathrm{~m}$ of sedimentary rocks, most of which de Recursos Hidráulicos, de la que se recuperaron $62 \mathrm{~m}$ de rocas sedimentarias, representadas en su mayoría por un paquete homogéneo de limolita gris clara de grano fino, fosilífera, de $51 \mathrm{~m}$ de espesor. A su vez, la limolita se encuentra cubierta por estratos delgados de arenisca y caliza (fig. 2).

Se obtuvieron 56 muestras de la columna sedimentaria, mismas que fueron lavadas y secadas de acuerdo con las técnicas micropaleontológicas convencionales para microfósiles calcáreos según Gonzalvo (2002). Los microfósiles fueron colocados en placas Plummer para su identificación taxonómica. Los especimenes identificados se encuentran alojados en la Colección Nacional de Paleontología del Museo María del Carmen Perilliat del Instituto de Geología de la Universidad Nacional Autónoma de México, UNAM (Especimenes IGM845-Mi a IGM-1053-Mi). Se tomaron micrografías de cada

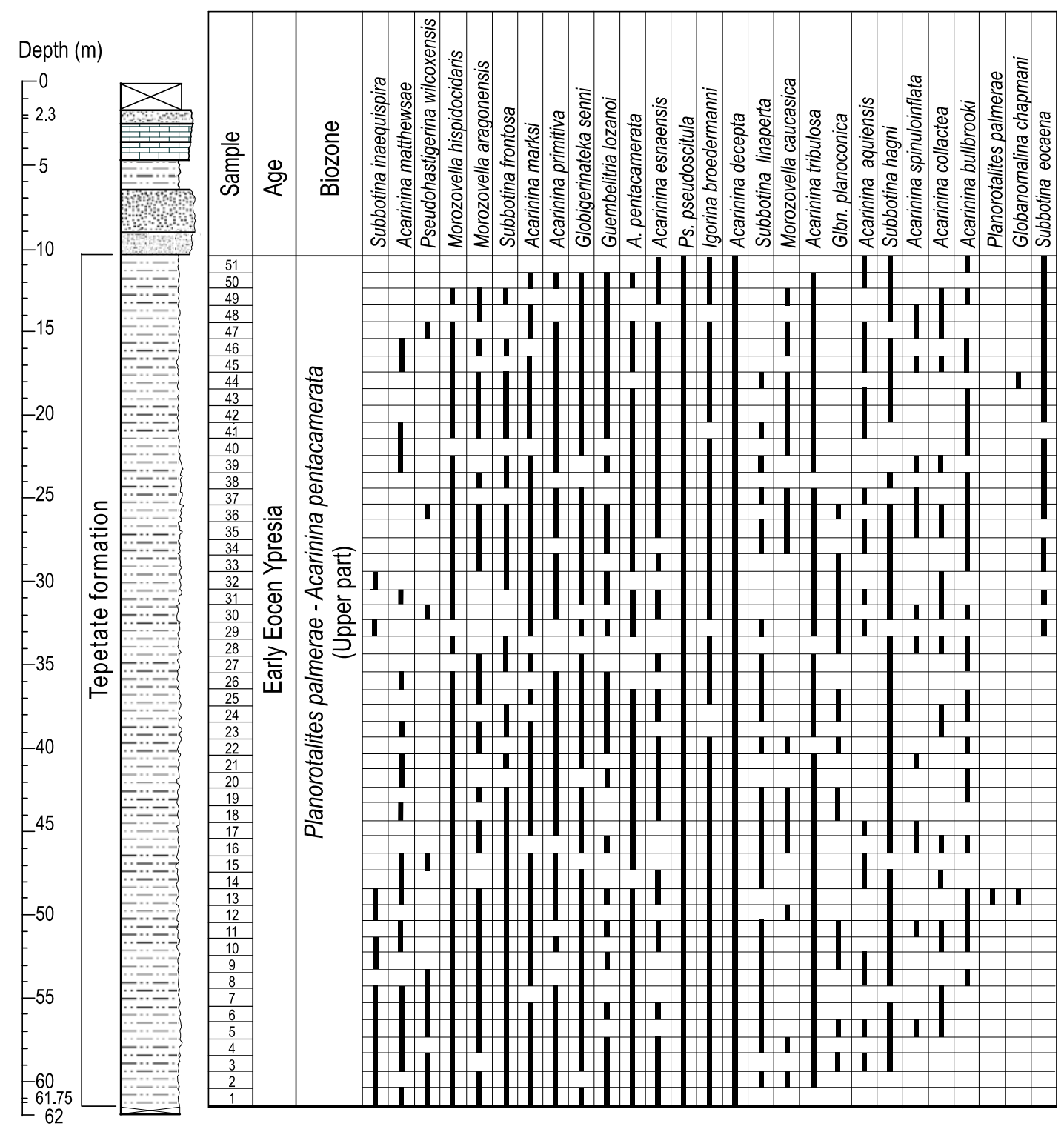

Figure 2. Distribution of planktonic foraminifers throughout the sedimentary column of Las Pocitas core.

Figura 2. Distribución de foraminíferos planctónicos a lo largo de la columna sedimentaria del núcleo Las Pocitas. 
consisted of homogeneous very light grey, fossiliferous, finegrained, 51-m-thick siltstone. The siltstone is capped by thin layers of sandstone and limestone (fig. 2).

Fifty-six samples were collected from the sedimentary column. These samples were washed and dried following standard micropaleontological techniques described by Gonzalvo (2002). The microfossils were picked and preserved on Plummer slides for later taxonomic identification. The specimens identified in this study are deposited in the National Paleontology Collection of the María del Carmen Perrilliat Museum of the Geology Institute at the National Autonomous University of Mexico (UNAM; IGM specimens 845-Mi to 1053-Mi). Micrographs of specimens were taken using the IGM JEOL-335C electron microscope. Three hundred specimens of planktonic and benthic foraminifera were counted in each sample in order to establish relative and total abundances, as well as frequency ratios between planktonic and benthic taxa.

\section{Results}

\section{Micropaleontology}

Only the five stratigraphically highest samples of the 56 samples collected did not contain microfossils. Based on their lithology and lack of microfossils, it is likely that these samples do not belong to the Tepetate Formation. The remaining 51 samples of Tepetate siltstone contained benthic and planktonic foraminifers, as well as ostracods.

Fifty-six genera of benthic foraminifers and 11 genera of planktonic foraminifers were identified following the taxonomic classification of Loeblich and Tappan (1988). A total of 151 species and subspecies were identified (appendix), three of which were left in open nomenclature (cf. and aff.). One hundred and eighteen are benthic foraminifera, identified following Cushman (1927), Cushman and McMasters (1936), Martin (1943), Bandy (1949), Israelsky (1955), and Mallory (1959). Thirty-three planktonic species were identified according to Cushman (1925), Martin (1943), Brönnimann (1952), LeRoy (1953), Loeblich and Tappan (1957), Bandy (1964), Gohrbandt (1967), Postuma (1971), Cifelli (1972), Stainforth et al. (1975), Berggren (1977), Blow (1979), Toumarkine and Luterbacher (1985), and Premoli-Silva et al. (2003).

Preservation of both foraminifers and ostracods was generally good in the core samples analyzed. Nevertheless, some specimens were broken and some showed signs of dissolution, whereas others displayed evidence of recrystallization (samples 11-12, 30-31, 47). The abundance of foraminifers was highest in samples 11, 35 and 41, and lowest in samples 25 to 29. Benthic taxa displayed higher diversity than planktonic forms in all samples. Highest benthic diversities occurred in samples 5, 18 and 40, whereas highest planktonic diversities occurred in samples 10, 11 and 36 .

The distribution of the foraminiferal assemblages was erratic throughout the sedimentary column sampled, except for espécimen en el microscopio electrónico de barrido (MEB) JEOL-335C.Se contaron 300 foraminíferos planctónicos y bentónicos con la intención de conocer su abundancia relativa y el total de especies por muestra, así como para estimar la proporción de frecuencias medias de taxones planctónicos y bentónicos.

\section{Resultados}

\section{Micropaleontología}

De las 56 muestras analizadas, sólo las cinco de la cima del núcleo no contuvieron microfósiles y, debido a sus características litológicas, es posible que éstas no pertenecieran a la formación Tepetate. Las 51 muestras pertenecientes al paquete de limolita contienen un conjunto de foraminíferos planctónicos y bentónicos, así como una rica variedad de ostrácodos.

Se identificaron 56 géneros de foraminíferos bentónicos y 11 de planctónicos empleando la clasificación de Loeblich y Tappan (1988). Se identificaron 151 especies y subespecies de foraminíferos (apéndice), tres de las cuales fueron dejadas en nomenclatura abierta (cf. y aff.). Ciento dieciocho son especies bentónicas que fueron identificadas con ayuda de los trabajos de Cushman (1927), Cushman y McMasters (1936), Martin (1943), Bandy (1949), Israelsky (1955), y Mallory (1959). Se identificaron 33 especies planctónicas, tomando como referencia a Cushman (1925), Martin (1943), Brönnimann (1952), LeRoy (1953), Loeblich y Tappan (1957), Bandy (1964), Gohrbandt (1967), Postuma (1971), Cifelli (1972), Stainforth et al. (1975), Berggren (1977), Blow (1979), Toumarkine y Luterbacher (1985), y Premoli-Silva et al. (2003).

La preservación de los foraminíferos y ostrácodos a todo lo largo del núcleo se considera buena; sin embargo, algunos especómenes están rotos y evidencian disolución, mientras que otros se encuentran recristalizados (muestras 11-12, 30-31, 47). La mayor abundacia de foraminíferos se encuentra en las muestras 11, 35 y 41 , mientras que la menor se registra en las muestras 25 a 29. A lo largo de todo el núcleo el conjunto de especies bentónicas muestra una diversidad mayor que el planctónico, particularmente en la muestras 5, 18 y 40, mientras que la mayor diversidad planctónica resultó en las muestras 10,11 y 36 .

A todo lo largo de la columna sedimentaria el conjunto de foraminíferos denota una distribución errática, con excepción de las especies dominantes como Planorotalites pseudoscitula Glaessner y Acarinina decepta Martín, entre las planctónicas (figs. 2, 3), y Anomalinoides judas Martin, Anomalinoides kennae Martin, Bolivina pisciformis Galloway y Morrey, Gyroidinoides soldanii d'Orbigny octocamerata Cushman y Hanna, Spiroloculina lamposa Hussey y Uvigerina lodoensis Martin var. miriamae Mallory, entre las especies bentónicas (figs. 4, 5). 


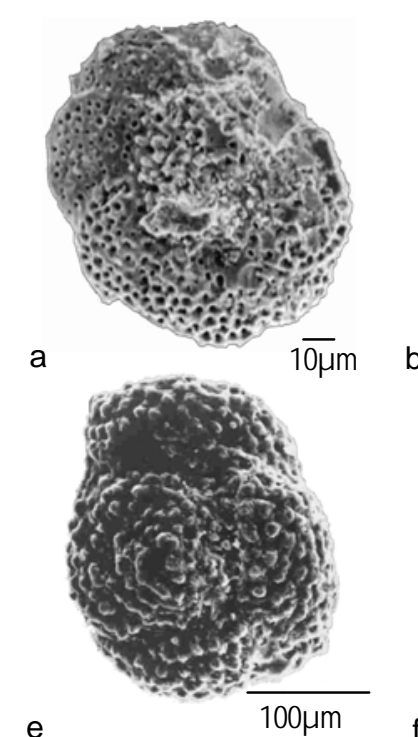

e

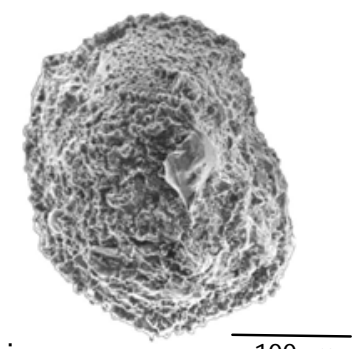

i

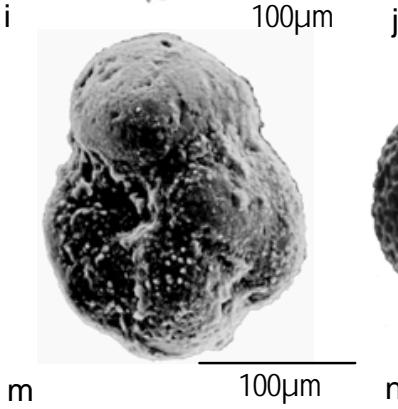

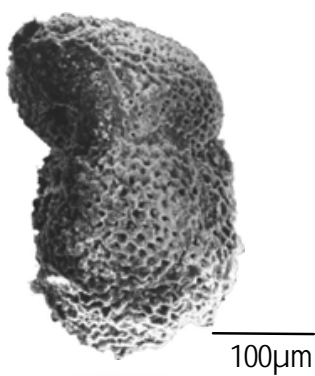

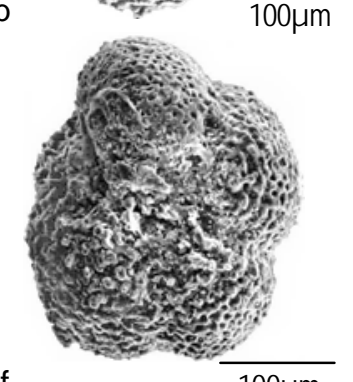

f
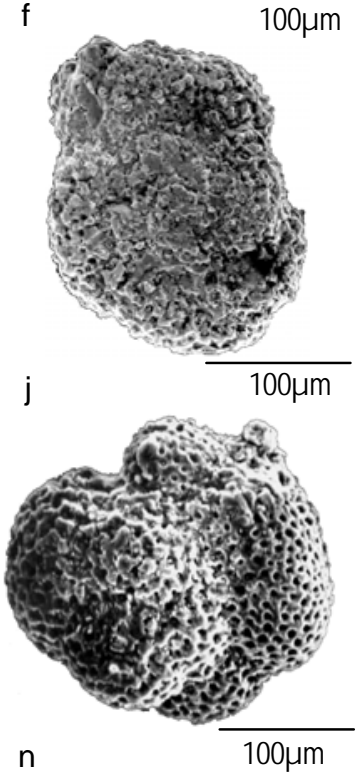

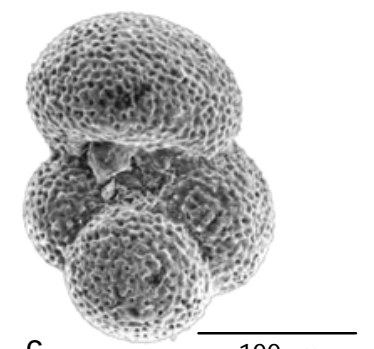

C

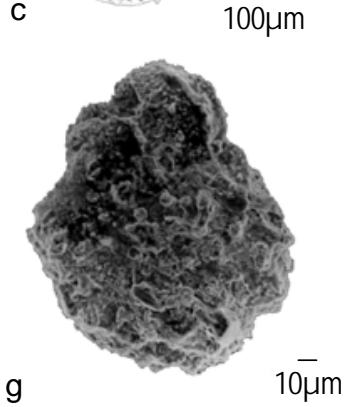

d

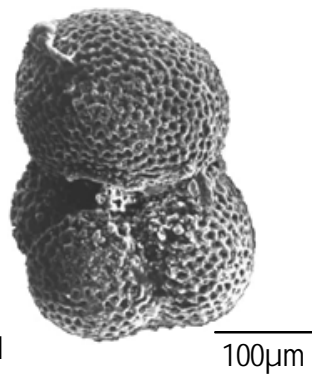

g
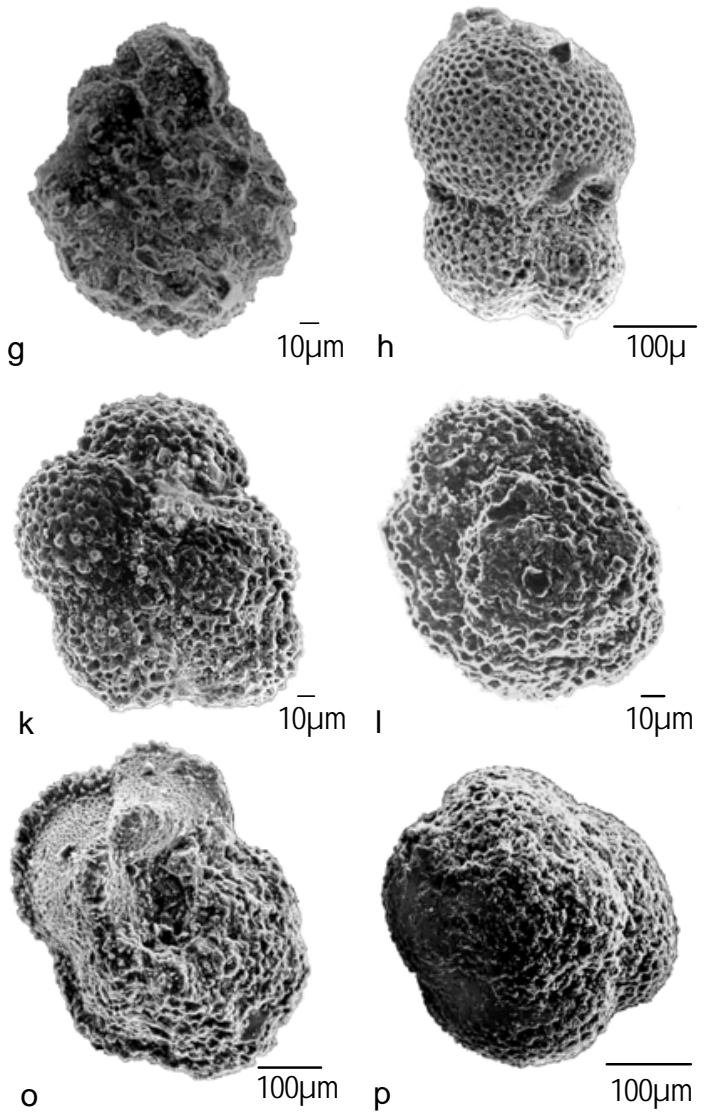

Figure 3. SEM micrographs of important biostratigraphic planktonic foraminifers in Las Pocitas core samples.

Figura 3. Micrografías al MEB de foraminíferos planctónicos con importancia bioestratigráfica presentes en muestras del núcleo Las Pocitas.

(a) Planorotalites pseudoscitula, (b) Acarinina decepta, (c) Subbotina inaequispira, (d) Subbotina eocaena, (e) Acarinina spinuloinflata, (f) Acarinina pentacamerata, (g) Planorotalites palmerae, (h) Subbotina frontosa, (i) Morozovella aragonensis, (j) Acarinina bullbrooki, (k) Acarinina collactea, (l) Morozovella hispidicidaris, (m) Globanomalina planoconica, (n) Acarinina aquiensis, (o) Morozovella caucasica, (p) Globigerinatheka senni.

the dominant planktonic species Planorotalites pseudoscitula Glaessner and Acarinina decepta Martin (figs. 2, 3), and the dominant benthic taxa Anomalinoides judas Martin, A. kennae Martin, Bolivina pisciformis Galloway and Morrey, Gyroidina soldanii d'Orbigny var. octocamerata Cushman and Hanna, Spiroloculina lamposa Hussey, and Uvigerina lodoensis Martin var. miriamae Mallory (fig. 4, 5).

\section{Biostratigraphy}

Taking into account the stratigraphic ranges of all species encountered in the Las Pocitas core, the entire assemblage is considered Paleogene in age (fig. 6). Moreover, with the

\section{Bioestratigrafía}

Tomando en cuenta el alcance estratigráfico de todas las especies de foraminíferos planctónicos recuperadas en el núcleo Las Pocitas, el conjunto indica una edad paleógena (fig. 6). Más aún, con excepción de Acarinina tribulosa Bolli, A. decepta, A. aquiensis Loeblich y Tappan, A. esnaensis Le Roy, A. marksi Martin, A. collactea (Finlay), Morozovella hispidicidaris Martin, Globonomalina chapmani (Parr), G. planoconica (Subbotina), Subbotina linaperta (Finlay) y S. inaequiespira Subbotina, cuyos alcances estratigráficos comienzan en el Paleoceno, y de Subbotina eocaena (Guembel), que llega hasta 


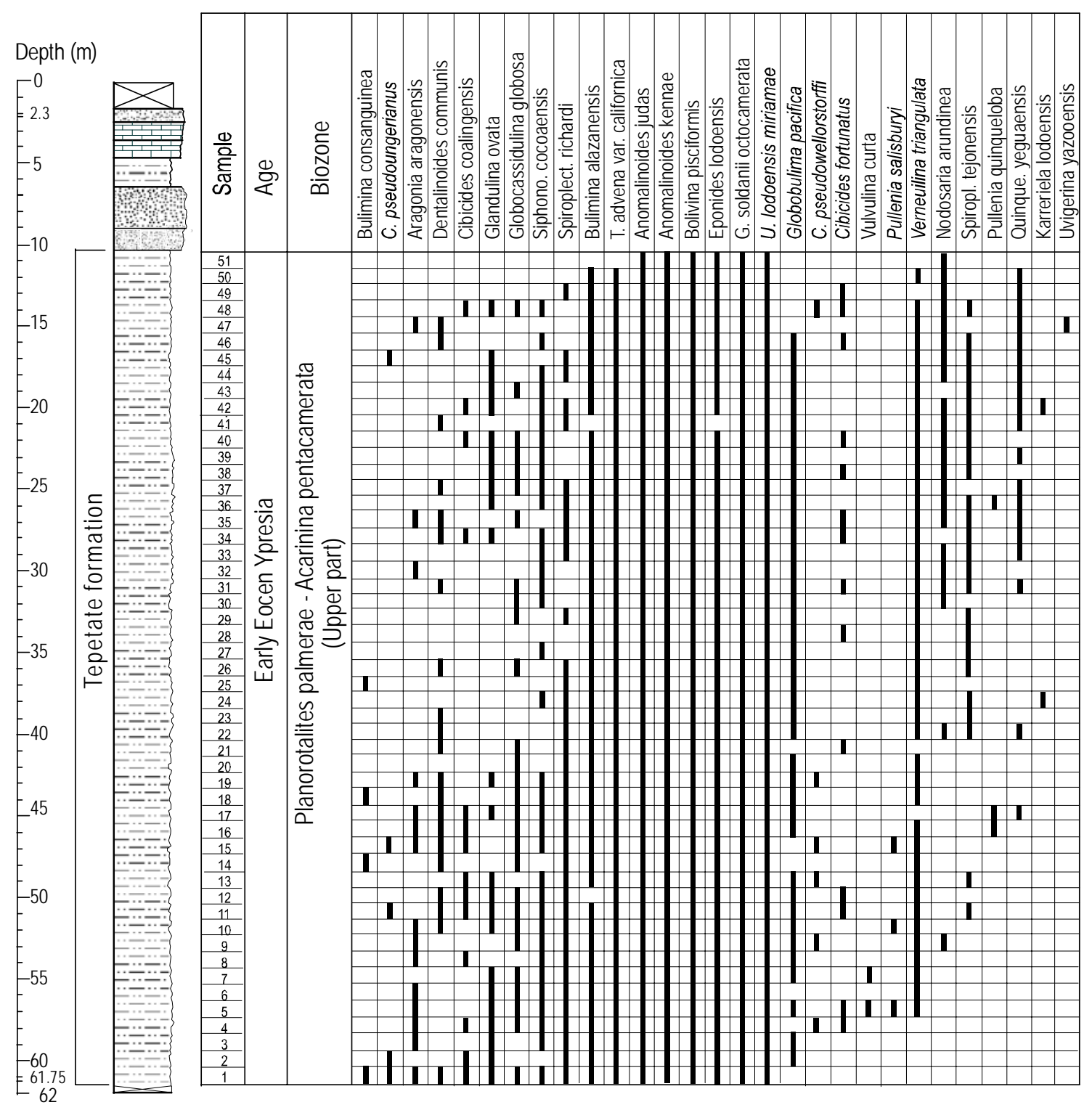

Figure 4. Distribution of benthic foraminifers throughout the sedimentary column of Las Pocitas core.

Figura 4. Distribución de foraminíferos bentónicos a lo largo de la columna sedimentaria del núcleo Las Pocitas.

exception of Acarinina tribulosa Bolli, A. decepta, A. aquiensis Loeblich and Tappan, A. esnaensis LeRoy, A. marksi Martin, A. collactea (Finlay), Morozovella hispidcidaris Martin, Globanomalina chapmani (Parr), G. planoconica (Subbotina), Subbotina linaperta (Finlay), and S. inaequiespira Subbotina, which range from the Paleocene through the Eocene, and S. eocaena (Guembel), which ranges into the Oligocene, the entire assemblage can be placed in the Eocene (fig. 6).

Given the established age ranges of the Eocene planktonic species found throughout the column sampled, the assemblage can be placed in Zone P9 (Planorotalites palmerae-Acarinina pentacamertata), which according to Premoli-Silva et al. (2003) is defined by the biostratigraphic interval between the first appearance datum (FAD) of P. palmerae (Cushman and el Oligoceno, el conjunto en su totalidad puede ser situado en el Eoceno (fig. 6).

Este conjunto de especies eocénicas distribuidas en toda la columna sedimentaria de Las Pocitas, con excepción de Acarinina spinuloinflata Bandy y Subbotina eocaena, puede representar un conjunto equivalente al de la Zona P9 Planorotalites palmerae-Acarinina pentacamerata de Premoli-Silva et al. (2003). De acuerdo a estos autores, la Zona P9 Planorotalites palmerae-Acarinina pentacamerata se define como el intervalo bioestratigráfico entre el DPA (datum de primera aparición) de Planorotalites palmerae (Cushman y Bermúdez) y el DPA de Hantkenina nuttalli Toumarkine, y está caracterizada, por la abundancia de Acarinina pentacamerata (Subbotina) y la co-ocurrencia de Subbotina frontosa (Subbotina), S. inaequispira Subbotina, Morozovella aragonensis (Nuttall) y 

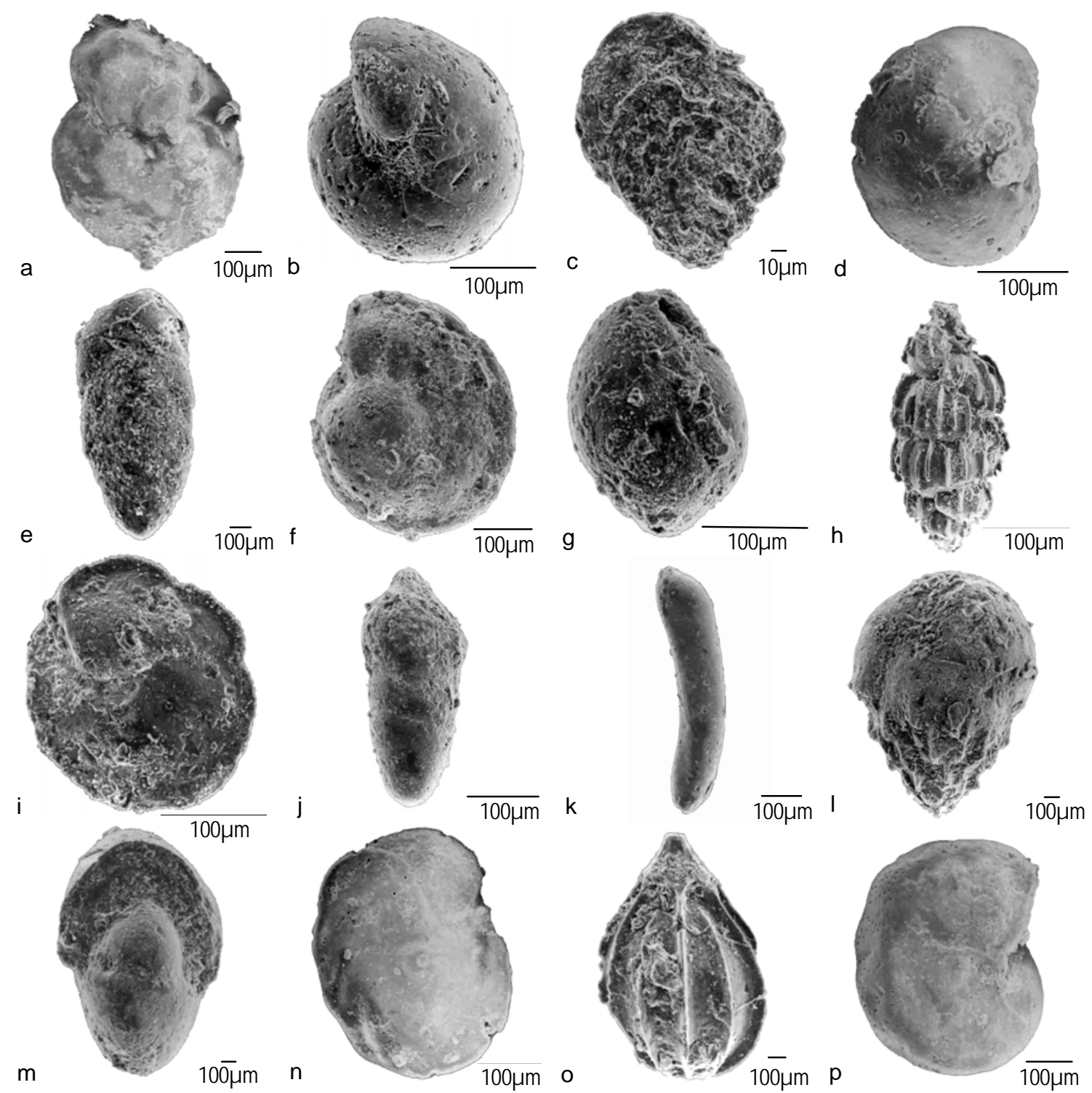

Figure 5. SEM micrographs of benthic foraminifers of paleobathymetric importance in Las Pocitas core samples.

Figura 5. Micrografías MEB de foraminíferos bentónicos indicadores de paleobatimetría presentes en muestras del núcleo Las Pocitas.

(a) Cibicides pseudowellorstorffi, (b) Gyroidinoides soldanii var. octocamerata, (c) Aragonia aragonensis, (d) Cibicides fortunatus, (e) Bolivina pisciformis, (f) Cibicidoides pseudoungerianus (g) Globobulima pacifica, (h) Uvigerina yazooensis, (i) Eponides lodoensis, (j) Glandulina ovata, (k) Dentalinoides communis, (I) Bulimina consanginea, (m) Pullenia quinqueloba, (n) Cibicides coalingensis, (o) Lagena acuticosta, (p) Anomalinoides kennae.

Bermúdez) and the FAD of Hantkenina nuttalli Tourmarkine. This interval is characterized by abundant specimens of $A$. pentacamerata (Subbotina), and by the co-occurrence of Subbotina frontosa (Subbotina), S. inaequispira Subbotina, Morozovella aragonensis (Nuttall), and Acarinina bullbrooki Bolli, all of which are present throughout the sedimentary column studied. Premoli-Silva et al. (2003) note that Acarinina mathewsae Blow and Subbotina hagni Gohrbandt have their FADs in the upper part of Zone P9 (Planorotalites palmeraeAcarina pentacamerata). The fact that these two taxa are continuously present in the samples studied suggests that the entire sedimentary column was deposited during the upper part of this biozone (fig. 6).
Acarinina bullbrooki Bolli, especies todas presentes en la columna sedimentaria estudiada. Más aún, la presencia continua de Acarinina mathewsae Blow y Subbotina hagni Gohrbandt en las muestras estudiadas, que según Premoli-Silva et al. (2003) tienen su DPA en la parte superior de la Zona P9 Planorotalites palmerae-Acarinina pentacamerata, refuerza la afirmación de que toda la columna estratigráfica se depositó durante la parte superior de esta zona (fig. 6).

Es importante mencionar, que en la sección estudiada, Acarinina spinuloinflata está presente de manera discontinua, mientras que Subbotina eocaena está sólo a partir de la muestra 29 y hasta la cima (fig. 2). De acuerdo con el esquema zonal de Premoli-Silva et al. (2003), Acarinina spinuloinflata tiene su 


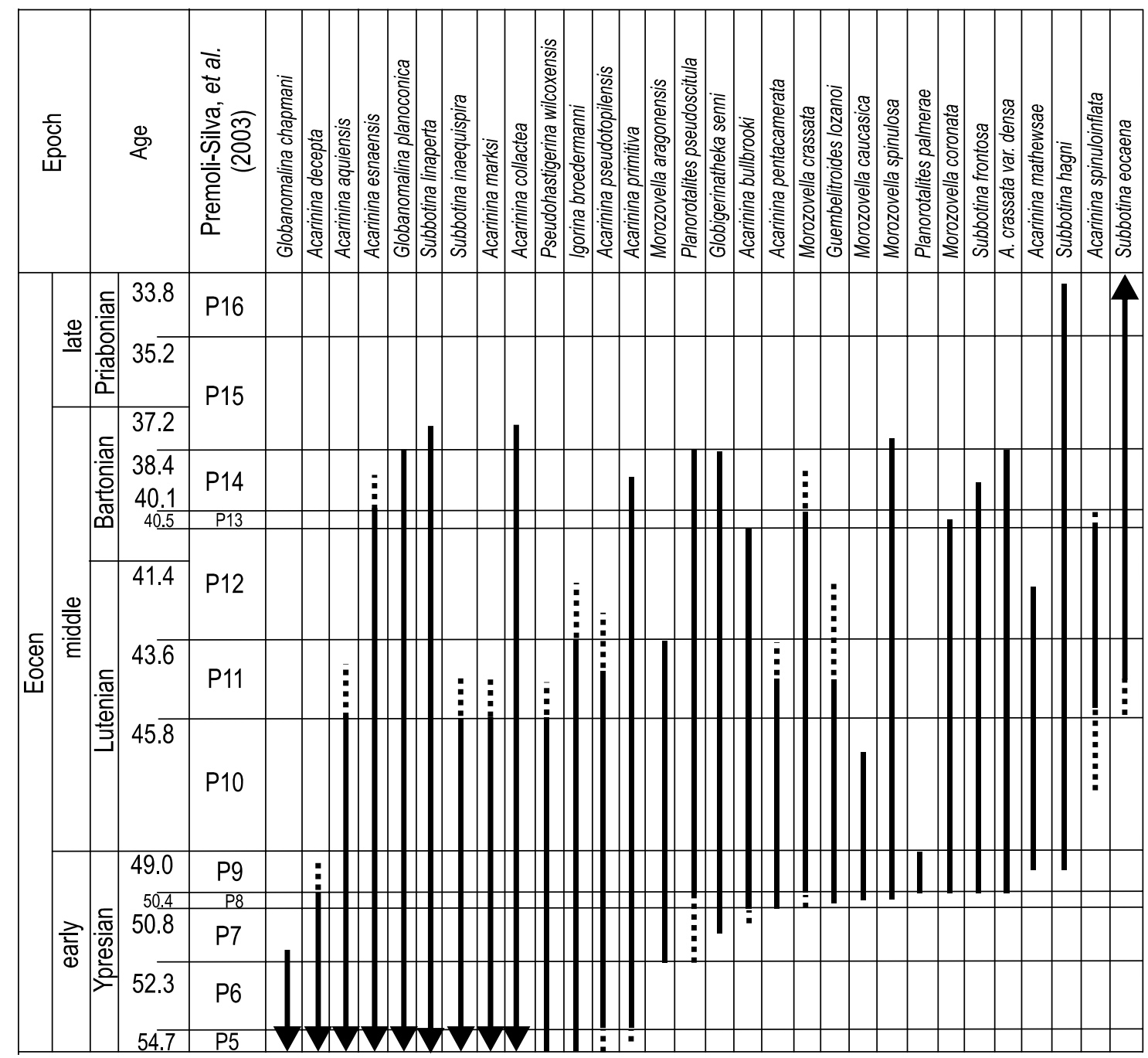

Figure 6. Stratigraphic ranges of Eocene index planktonic foraminifers and zones according to Premoli-Silva et al. (2003).

Figura 6. Alcances estratigráficos de los foraminíferos planctónicos índices del Eoceno de acuerdo con Premoli-Silva et al. (2003).

It is important to note that Acarinina spinoinflata is discontinuously present throughout the sedimentary column (fig. 2), whereas Subbotina eocaena is present from the middle part of the column (sample 29) to the top. According to Premoli-Silva et al. (2003), A. spinoinflata has its first stratigraphic occurrence in the middle part of Zone P10 (Hantkenina nuttalli), whereas $S$. eocaena has its first occurrence at the base of Zone P11 (Globigerinatheka subconglobata subconglobata), both within the middle Eocene. In constrast, Toumarkine and Luterbacher (1985) placed the FAD of A. spinoinflata at the base of Zone P9 and that of S. eocaena in the middle of the same zone, matching the observations made in this study. Finally, the absence of the genus Hantkenina (a world-wide bioevent) in the samples analyzed prevents a younger age assignment for this part of the Tepetate Formation.

Most of the standard Eocene zonal schemes were established in tropical-subtropical areas using planktonic taxa characteristic of warm water masses. Thus, discrepancies in the
DPA en la parte media de la Zona P10 Hantkenina nuttalli; mientras que el DPA de Subbotina eocaena ocurre en la base de la Zona P11 Globigerinatheka subconglobata subconglo bata, ambas del Eoceno medio. Sin embargo, Toumarkine y Luterbacher (1985) sitúan el DPA de Acarinina spinuloinflata en la base de la Zona P9 y el de Subbotina eocaena en la parte media de la misma zona, lo cual concuerda con las observaciones realizadas en este estudio. Más aún, la ausencia del Género Hantkenina, bioevento cosmopolita, previene la asignación de una edad más joven para esta parte de la formación Tepetate.

Los esquemas zonales establecidos para el Eoceno se desarrollaron en áreas tropicales a subtropicales usando taxones planctónicos característicos de masas de agua cálida. Por tal motivo, la discrepancia en la distribución estratigráfica de algunos taxones planctónicos en las muestras aquí estudiadas, sugiere la ubicación de esta localidad en un área subtropical a templada para finales del Eoceno temprano. Para este intervalo de tiempo se ha documentado el inicio de un enfriamiento cli- 


\begin{tabular}{|c|c|c|c|}
\hline \multirow{2}{*}{ Benthic foraminifera } & \multicolumn{2}{|c|}{ Depositional environments } & \multirow{2}{*}{$\begin{array}{c}\text { Bathymetry } \\
\text { (mts) }\end{array}$} \\
\hline & $\begin{array}{l}\text { Outer } \\
\text { shelf }\end{array}$ & Continental slope & \\
\hline Globocassidulina globosa & & & \multirow{3}{*}{$\begin{array}{c}\text { Outer } \\
\text { neritic } \\
-150\end{array}$} \\
\hline Spiroplectammina richardi & & & \\
\hline \multicolumn{3}{|l|}{ Pullenia salisbury } & \\
\hline \multicolumn{3}{|l|}{ Aragonia aragonensis } & \multirow{5}{*}{$\begin{array}{l}\text { Superior } \\
\text { bathyal }\end{array}$} \\
\hline \multicolumn{3}{|l|}{ Cibicides fortunatus } & \\
\hline \multicolumn{3}{|l|}{ Cibicidoides pseudoungerianus } & \\
\hline \multicolumn{3}{|l|}{ Cibicides pseudowellerstorfi } & \\
\hline \multicolumn{3}{|l|}{ Globobulimina pacifica } & \\
\hline \multicolumn{3}{|l|}{ Uvigerina yazooensis } & \multirow{5}{*}{$\begin{array}{l}\text { Mid- } \\
\text { superior } \\
\text { bathyal }\end{array}$} \\
\hline \multicolumn{3}{|l|}{ Bolivina pisciformis } & \\
\hline \multicolumn{3}{|l|}{ Bulimina consanguinea } & \\
\hline \multicolumn{3}{|l|}{ Eponides lodoensis } & \\
\hline \multicolumn{3}{|l|}{ Pullenia quinqueloba } & \\
\hline \multicolumn{3}{|l|}{ Cibicides coalingensis } & \multirow{4}{*}{$\begin{array}{l}\text { Lower } \\
\text { superior } \\
\text { bathyal } \\
2000\end{array}$} \\
\hline \multicolumn{3}{|l|}{ Bulimina alazanensis } & \\
\hline \multicolumn{3}{|l|}{ Vulvulina curta } & \\
\hline Gyroidinoides soldanii & & & \\
\hline
\end{tabular}

Figure 7. Estimated paleobathymetric ranges, according to Ingle (1980), of selected benthic foraminifers identified in Las Pocitas core samples. Figura 7. Rangos paleobatimétricos de acuerdo a Ingle (1980) de algunos foraminíferos bentónicos identificados en muestras del núcleo Las Pocitas.

stratigraphic distributions of planktonic taxa in the samples studied likely reflect the subtropical-temperate setting of the Tepetate location at the end of the early Eocene. In addition, faunal and stable isotope evidence indicates that pronounced climatic cooling commenced at the end of the early Eocene (Steineck and Gibson 1971, Zachos et al. 2001), an event that expanded the influence of temperate water masses. These conditions affected the biogeographic ranges of species and ultimately their stratigraphic ranges. Therefore, it is possible that the stratigraphic ranges of $A$. spinoinflata and S. eocaena in the subtropical-temperate Tepetate location differ relative to their distribution in entirely tropical regions.

\section{Paleoenvironment}

According to Ingle (1980), benthic foraminifers identified in the Tepetate rocks, such as Spiroplectammina richardi Martin and Globocassidulina globosa Hantken, have upper depth limits in the outer shelf biofacies, like Pullenia salisburyi (Stewart and Stewart), which even occurs in upper bathyal biofacies (Smith 1964). The deepest paleobathymetric ranges come from Vulvulina curta Cushman and Siegfus, Cibicides coalingensis (Cushman and Hanna), and Bulimina alazanensis Cushman, with upper depth limits in lower middle bathyal biofacies, and Gyroidinoides soldanii d'Orbigny in lower bathyal biofacies along the East Pacific margin (fig. 7).

Nevertheless, the most abundant, well-preserved and frequently occurring benthic taxa are indicative of upper bathyal water depths (Ingle 1980) and include Aragonia aragonensis (Nuttall), Cibicides fortunatus Martin, Cibicidoides pseudoungerianus Cushman, Cibicides pseudowellerstorfi Cole, Globobulimina pacifica (Cushman), and Uvigerina mático muy drástico (Steineck y Gibson 1971, Zachos et al. 2001) evidenciado por isótopos estables y microfósiles que favoreció la proliferación de masas de agua frías. Bajo estas condiciones, no es inusual que las especies sufrieran cambios en su distribución biogeográfica, así como en su alcance estratigráfico. Por lo tanto, es posible que los alcances estratigráficos de A. spinuloinflata y S. eocaena difieran en el área de estudio con respecto a su distribución en regiones netamente tropicales.

\section{Paleoambiente}

Las especies de foraminíferos bentónicos identificadas en las rocas pertenecientes a la formación Tepetate como Spiroplectammina richardi Martin y Globocassidulina globosa Hantken, son, de acuerdo con Ingle (1980), parte de un conjunto característicamente nerítico externo, al igual que Pullenia salisburyi (Stewart y Stewart) que incluso se presenta en biofacies del batial superior (Smith 1964). Los rangos paleobatimétricos más profundos pertenecen a Vulvulina curta Cushman y Siegfus, Cibicides coalingensis (Cushman y Hanna) y Bulimina alazanensis Cushman, con límites superiores de profundidad en el batial medio inferior, y Gyroidinoides soldanii en el batial inferior a lo largo de la margen oriental del Pacífico. Sin embargo, los taxones bentónicos más abundantes, bien preservados y de mayor frecuencia como Aragonia aragonensis (Nuttall), Cibicides fortunatus Martin, Cibicidoides pseudoungerianus Cushman, Cibicides pseudowellerstorfi Cole, Globobulimina pacifica (Cushman) y Uvigerina yazooensis Cushman, son especies comunes en el batial superior (Ingle, 1980). Otras especies dominantes asociadas a este conjunto tienen límites de profundidad en el batial medio superior como 
yazooensis Cushman. Other associated species have upper depth limits in the upper middle bathyal biofacies, such as Eponides lodoensis Martin, Bolivina pisciformis Galloway and Morrey, Bulinina consanguinea Parker and Bermúdez, and Pullenia quinqueloba (Reuss). This faunal association suggests that deposition likely occurred at a water depth of $c a .500 \mathrm{~m}$ near the boundary of the upper bathyal and upper middle bathyal zones (fig. 7).

\section{Discussion}

The distribution of planktonic foraminifers within the section analyzed allows recognition of the late early Eocene Zone P9 (Planorotalites palmerae-Acarinina pentacamerata) following Premoli-Silva et al. (2003). Berggren et al. (1995) assigned this biozone an age span of 50.4 to $49 \mathrm{Ma}$. This age is coherent with the age of 49.5 to 49 Ma assigned by GarcíaCordero (pers. comm. 2006) based on a biostratigraphic analysis of calcareous nannoplankton in the same set of samples used in this study. The age is also in general agreement with data provided by Vázquez-García (1996) for Tepetate sediments from Arroyo El Conejo, and by Guerrero-Arenas (1998) and Carreño et al. (2000) for Arroyo Colorado.

Based on species previously reported for Tepetate sediments from Arroyo Datilar, including Planorotalites palmerae, Globigerinatheka senni Beckman, and Acarinina aspensis Colom, together with the absence of Hantkenina, it is possible to assign these exposures to Zone P9 (Planorotalites palmeraeAcarinina pentacamerata), rather than to Zones P8 (Morozovella aragonensis) and P10 (Hantkenina nuttalli) established by Knappe (1974). Benthic foraminifers indicate that the Tepetate sediments studied were deposited at an upper bathyal water depth of $c a .500 \mathrm{~m}$, in agreement with interpretations of Tepetate sediments studied at other localities including arroyos Datilar and El Conejo (Knappe 1974), arroyos Salada and Colorado (Fullwider 1976, Galli-Oliver et al. 1986), and Las Pocitas (Ledesma-Vázquez et al. 1999, García-Cordero 2005).

This study, together with interpretations of shallower water environments made by Heim (1922), Mina-Uhink (1957), Vázquez-García (1996), Guerrero-Arenas (1998), LedesmaVázquez et al. (1999), and Carreño et al. (2000), suggest that an irregular paleotopography prevailed in the study area during Paleogene time. This, in turn, favoured the deposition of different facies. Carreño et al. (2000) inferred, on the basis of the associated lithology and the foraminiferal assemblage at several localities, that the entire unit seems to have been deposited during a transgressive event followed by an important regressive event. Continental conditions prevailed in the area, at least throughout the late Oligocene, when the marine deposit of the El Cien Formation occurred.

Data from this study, together with information provided by the above-cited authors, strongly suggest that the Tepetate Formation spans an interval of time from the early Paleocene to the early middle Eocene, indicating the presence of a short son Eponides lodoensis Martin, Bolivina pisciformis Galloway y Morrey, junto con Bulinina consanguinea Parker y Bermudez y Pullenia quinqueloba (Reuss). Esta asociación faunística sugiere que los sedimentos de la formación Tepetate en el núcleo Las Pocitas se depositaron entre el batial superior y medio superior, aproximadamente a $500 \mathrm{~m}$ de profundidad, en un ambiente del talud continental (fig. 7).

\section{Discusión}

La distribución de los foraminíferos planctónicos a lo largo de la sección estudiada, permitió el reconocimiento de un conjunto característico de la Zona P9 Planorotalites palmeraeAcarinina pentacamerata de Premoli-Silva et al. (2003) correspondiente a la parte tardía del Eoceno temprano, misma que de acuerdo con Berggren et al. (1995) comprende una edad de entre 50.4 y 49 Ma. Esta edad es coherente con la edad establecida por García-Cordero y Carreño (2008) de entre 49.5 y 49 Ma para las mismas muestras. De igual forma, concuerda de manera general, con las edades asignadas para la formación Tepetate en Arroyo El Conejo por Vázquez-García (1996) y en Arroyo Colorado por Guerrero-Arenas (1998) y Carreño et al. (2000).

Considerando las especies reportadas previamente por Knappe (1974) en Arroyo Datilar, se deduce que con base en la presencia de Planorotalites palmerae, Globigerinatheka senni Beckmann y Acarinina aspensis Colom, y debido a la ausencia de Hantkenina, es posible asignar a las rocas que afloran en esta localidad a la Zona P9 Planorotalites palmerae-Acarinina pentacamerata, en lugar de a la zonas P8 Morozovella aragonensis y P10 Hantkenina nuttalli establecidas por Knappe (1974). El conjunto de foraminíferos bentónicos indica que las rocas aquí estudiadas pertenecientes a la formación Tepetate se depositaron entre el batial superior y medio superior a una profundidad de por lo menos $500 \mathrm{~m}$ en un ambiente del talud medio, concordando con las interpretaciones hechas por otros autores en diversas localidades donde afloran rocas de esta formación, como en los arroyos Datilar y El Conejo (Knappe, 1974), los arroyos Salada y Colorado (Fullwider 1976, GalliOliver et al. 1986), y Las Pocitas (Ledesma-Vázquez et al. 1999, García-Cordero 2005).

Esta información, así como la interpretación de la presencia de ambientes someros y costeros realizada por Heim (1922), Mina-Uhink (1957), Vázquez-García (1996), Guerrero-Arenas (1998), Ledesma-Vázquez et al. (1999) y Carreño et al. (2000), sugiere que durante el Paleógeno prevaleció una topografía irregular que favoreció el depósito de facies diferentes. Carreño et al. (2000) con base en evidencia litológica y en el conjunto de foraminíferos sugiere que la unidad en su totalidad parece haberse depositado durante un evento transgresivo seguido de una importante regresión. Las condiciones continentales prevalecieron en el área, al menos hasta el Oligoceno tardío, cuando se presentan los depósitos marinos de la Formación El Cien. 
depositional hiatus in the middle Paleocene. The Cretaceous age assigned to basal Tepetate rocks by Fullwider (1976) and Coleman (1979) remains an isolated record. However, GarcíaCordero and Carreño (2008) noted the continuous presence of abundant re-worked Cretaceous species of calcareous nannoplankton in the Las Pocitas core samples, suggesting a nearby source of Cretaceous rocks. Another isolated record that is still not supported by any other fossil group is the one reported by González-Barba (2002), who assigned a late Eocene (Priabonian) age to the Tepetate Formation based on the study of fossil shark and ray remains.

The presence in the samples studied of planktonic foraminiferal taxa thought to be characteristic of temperate water assemblages, including Globanomalina planoconica and Acarinina collactea (Steineck and Gibson 1971), along with the lower diversity of the planktonic fauna and flora, the scarcity of keeled globorotalids (Morozovella), the dominance of globigerinids (Subbotina), and the presence of ostracod species of the cryophilic genera Krithe and Parakrithe, point to a subtropical-temperate oceanographic setting (Steineck et al. 1972). This interpretation agrees with evidence indicating the occurrence of significant climate cooling at the end of the early Eocene through the Oligocene (Steineck and Gibson 1971, Berggren and Prothero 1992, Berggren et al. 1998, Zachos et al. 2001), reinforcing the interpretations made by LedesmaVázquez et al. (1999), who suggested the probable occurrence of cool water masses in the area of Las Pocitas.

Based on the results of this study, the earlier proposal to designate the Las Pocitas core as the type section of the Tepetate Formation is not considered appropriate. The 62-mthick section recovered represents only the younger part of the lithostratigraphic unit and, based on the lithology observed, the column can be assigned to the informal interbedded member of Fullwider (1976). Therefore, it was not possible to formalize the nomenclatural status of this unit on the basis of the sedimentary column studied.

\section{Acknowledgements}

The authors thank UABCS for permission to use the material analyzed here. We are indebted to J Ingle (Stanford University), J Ledesma-Vázquez (UABC), and K McDougall (USGS at Flagstaff) for their critical review and suggestions that substantially improved the manuscript, and to M Alcayde (technical editor of the Institute of Geology, UNAM) for the revision and correction of the manuscript in both languages. This study was partially supported by grant PAPIIT-IN116308.

\section{References}

Bandy OL. 1949. Eocene and Oligocene foraminifera from Little Stave Creek, Clarke County, Alabama. Bull. Am. Paleontol. 32: $1-211$.

Bandy OL. 1964. The type of Globorotalia crassata (Cushman). Contrib. Cushman Found. Foraminifer. Res. 15: 34-35.

Beal HC. 1948. Reconnaissance of the geology and oil possibilities of Baja California, Mexico. Geol. Soc. Am. Mem. 31, 138 pp.
Los datos aquí presentados, así como la información propuesta por los autores antes mencionados, sugieren que el depósito de la formación Tepetate incluye un intervalo de tiempo que va del Paleoceno temprano, hasta la parte temprana del Eoceno medio, indicando la presencia de un hiatus deposicional corto durante el Paleoceno medio. La edad cretácica asignada por Fullwider (1976) y Coleman (1979) para la base de la formación Tepetate, permanece como un dato aislado. Sin embargo, García-Cordero y Carreño (2008) mencionan la presencia continua y abundante de especies cretácicas retrabajadas a través del núcleo de Las Pocitas, sugiriendo la existencia de una fuente de rocas cretácicas cercana al área de estudio. Otro dato aislado que aún no ha sido corroborado por otro grupo fósil es el mencionado por González-Barba (2002), quien adjudica una edad del Eoceno tardío (Priaboniano) para la formación Tepetate con base en la descripción de una asociación de tiburones y rayas fósiles.

La presencia de especies planctónicas características de masas de agua templada en las muestras estudiadas, tales como Globanomalina planoconica y Acarinina collactea (Steineck y Gibson 1971), aunada a la baja diversidad de la fauna y flora planctónica, la escasez de globorotálidos quillados (Morozovella), la predominancia de globigerínidos (Subbotina) y la presencia de especies de ostrácodos de los géneros criófilos Krithe y Parakrithe, apoyan la interpretación sobre la presencia de masas de agua subtropical-templada (Steineck et al. 1972). Éstas pudieron haberse originado como resultado del enfriamiento climático ocurrido hacia finales del Eoceno y durante el Oligoceno, documentado por varios autores en otras regiones (Steineck y Gibson 1971, Berggren y Prothero 1992, Berggren et al. 1998, Zachos et al. 2001). Al mismo tiempo se refuerza la inferencia sobre la presencia de masas de agua fría asociada al depósito que aflora en el área de Las Pocitas, previamente documentado por Ledesma-Vázquez et al. (1999).

Los resultados del presente estudio no permiten considerar al conjunto de rocas marino-sedimentarias recuperado en el núcleo de Las Pocitas como candidato a representar la sección típica de la formación Tepetate debido a que la sección de $62 \mathrm{~m}$ de espesor representa sólo la parte superior de la unidad. De acuerdo con los atributos líticos de la columna sedimentaria estudiada, ésta corresponde al miembro informal interbedded de Fullwider (1976), y de ella están ausentes los otros dos miembros. Por tanto, no es posible con base en ella formalizar el status de nomenclatura de esta unidad.

\section{Agradecimientos}

Se agradece a la Universidad Autónoma de Baja California Sur el acceso al material bajo su resguardo para la realización de este trabajo. Las autoras agradecen a J Ingle (Stanford University), J Ledesma-Vázquez (UABC) y K McDougall (USGS, Flagstaff) por la revisión crítica y las sugerencias que mejoraron sustancialmente el escrito. Un reconocimiento para $\mathrm{M}$ Alcayde-O, Editora Técnica de las Publicaciones del Instituto de Geología, por la revisión y corrección del manuscrito en 
Berggren WA. 1977. Atlas of Paleogene planktonic foraminifera: Some species of the genera Subbotina, Planorotalites, Morozovella, Acarinina and Truncorotaloides. In: Ramsay ATS (ed.), Oceanic Micropaleontology. Academic Press, London, pp. 205-299.

Berggren WA, Prothero DR. 1992. Eocene-Oligocene climatic and biotic evolution: An overview. In: Prothero DR, Berggren WA (eds.), Eocene-Oligocene Climatic and Biotic Evolution. Princeton Univ. Press, New Jersey, pp. 1-28.

Berggren WA, Kent DV, Swisher CC, Aubry MP. 1995. A revised Cenozoic geochronology and chronostratigraphy. In: Berggren WA, Kent DV, Aubry MP, Hardenbol J (eds.), Geochronology, Time scale and Global Stratigraphic Correlations. SEPM Spec. Publ. 54: 129-212.

Berggren WA, Lucas S, Aubry MP. 1998. Late Paleocene-early Eocene climatic and biotic evolution: An overview. In: Aubry M, Lucas S, Berggren WA (eds.), Late Paleocene-Early Eocene Climatic and Biotic Events in the Marine and Terrestrial Records. Columbia Univ. Press, New York, pp. 1-17.

Blow WH. 1979. The Cainozoic Globigerinida: A study of the morphology, taxonomy and evolutionary relationships and the stratigraphical distribution of some Globigerinida (mainly Globigerinacea). 3 Vols. EJ Brill, Leiden, 1413 pp.

Bolli HM. 1966. Zonation of Cretaceous to Pliocene marine sediments based on planktonic foraminifera. Bol. Inf. Asoc. Venez. Geol. Min. Pet. 9: 3-32.

Brönnimann P. 1952. Trinidad Paleocene and lower Eocene Globigerinidae. Bull. Am. Paleontol. 34(143): 1-34.

Carreño AL, Ledesma-Vázquez J, Guerrero-Arenas R. 2000. Bioestratigrafía e historia deposicional de la formación Tepetate en el Arroyo Colorado (Eoceno medio-temprano), Baja California Sur, México. Cienc. Mar. 26: 177-200.

Ciffeli R. 1972. The holotype of Pulvinulina crassata var. densa Cushman and Globigerina spinuloinflata (Bandy). J. Foraminifer. Res. 2: 157-159.

Coleman TA. 1979. Nannoplankton biostratigraphy of the Tepetate Formation, Baja California del Sur. Unpublished MSc thesis, University of Southern California, $61 \mathrm{pp}$.

Cushman JA. 1925. An Eocene fauna from the Moctezuma River, Mexico. Bull. Am. Assoc. Pet. Geol. 9: 298-303.

Cushman JA. 1927. Foraminifera from the Eocene near San Diego, California. Trans. San Diego Soc. Nat. Hist. 5: 45-64.

Cushman JA, McMasters JH. 1936. Middle Eocene Foraminifera from the Llajas Formation, Ventura County, California. J. Paleontol. 10: 74-77.

Darton NH. 1921. Geological reconnaissance in Baja California. J. Geol. 29: 720-748.

Fullwider WR. 1976. Biostratigraphy of the Tepetate Formation, Baja California Sur. Unpublished MSc thesis, University of Southern California, 111 pp.

Galli-Olivier C, Márquez-Enríquez TE, Reyes-Sarabia JA, RosasCortés C. 1986. Estructuras sedimentarias primarias y litofacies de corrientes densas de un paleoambiente de talud, El Conejo, Baja California Sur, México. Cienc. Mar. 12(12): 7-15.

García-Cordero E. 2005. Estudio bioestratigráfico basado en nanoplancton calcáreo del núcleo Las Pocitas, formación Tepetate, Baja California Sur, México. In: Resúmenes. VII Reunión Internacional sobre Geología de la Península de Baja California. Ensenada, Baja California, México. Universidad Autónoma de Baja California Sur, 60 pp.

García-Cordero E, Carreño AL. 2008. Upper lower Eocene calcareous nannoplankton from the Las Pocitas Core (Tepetate Formation), Baja California Sur, Mexico. Rev. Mex. Cienc. Geol. 25(3) (in press). ambos idiomas. Esta investigación fue parcialmente apoyada por PAPIIT-IN116308.

Gohrbandt KHA 1967. Some new planktonic foraminiferal species from Austrian Eocene. Micropaleontology 13: 319-326.

González-Barba G. 2002. Asociaciones faunísticas de tiburones y rayas fósiles del Eoceno superior (Priaboniano) de las formaciones Tepetate y Bateque de Baja California Sur, México. In: Resúmenes, VIII Congreso Nacional de Paleontología. Guadalajara, México. Museo de Paleontología de Guadalajara, 139 pp.

Gonzalvo C. 2002. Metodología: Muestreos, técnicas de preparación y métodos de estudio. In: Molina E (ed.), Micropaleontología. Colección Textos Docentes. Prensas Universitarias de Zaragoza, $634 \mathrm{pp}$.

Gradstein FM, Ogg JG. 2005. Time scale. In: Cocks L, Robin M, Plimer IR (eds.), Encyclopedia of Geology. Vol. 5. Elsevier Publ., pp. 503-520.

Guerrero-Arenas R. 1998. Foraminíferos y ostrácodos de la localidad tipo de la formación Tepetate en Baja California Sur, México: Implicaciones bioestratigráficas y paleoambientales. Tesis de licenciatura inédita, Facultad de Ciencias, Universidad Nacional Autónoma de México, 53 pp.

Heim A. 1922. Notes on the Tertiary of southern Lower California. Geol. Mag. 59: 529-547.

Ingle JC Jr. 1980. Cenozoic paleobathymetry and depositional history of selected sequences within the southern California continental borderland. Cushman Found. Spec. Publ. 19: 163-195.

Israelsky MC. 1955. Foraminifera of the Lodo Formation, Central California. Prof. Pap. US Geol. Surv. 240-B: 31-76.

Knappe R Jr. 1974. The micropaleontology of a section of the Tepetate Formation and a comparison with equivalent foraminifera along the west coast of the United States. Unpublished MSc thesis, Ohio University, Athens, Ohio, 114 pp.

Ledesma-Vázquez J, Rendón-Márquez G, Carreño AL. 1999. Ambientes sedimentarios en la sección arroyo Colorado, formación Tepetate (Eoceno temprano-medio), Baja California Sur, México. GEOS 19: 78-83.

LeRoy LW. 1953. Biostratigraphy of the Maqfi Section, Egypt. Geol. Soc. Am. Mem. 54: p. 31, pl. 6.

Loeblich AR Jr, Tappan H. 1957. Planktonic foraminifera of Paleocene and early Eocene age from the Gulf and Atlantic coastal plains. Bull. US Nat. Mus. 215: 173-198.

Loeblich AR Jr, Tappan H. 1988. Foraminiferal Genera and their Classification. Van Nostrand Reinhold, New York, 2 Vols: 970 and 212 pp., 847 plates.

Lozano-Romen F. 1975. Evaluación petrolífera de la península de Baja California. Bol. Asoc. Mex. Geol. Pet. 27: 329 pp.

Mallory VS. 1959. Lower Tertiary Biostratigraphy of the California Coast Ranges. American Association Petroleum Geologists, 416 pp.

Martin LT. 1943. Eocene foraminifera from the type Lodo Formation, Fresno County, California. Stanford Univ. Publ. Geol. Sci. 3: 93125.

Mina-Uhink F. 1957. Bosquejo geológico del territorio sur de la Baja California. Bol. Asoc. Mex. Geol. Pet. 9: 188-192.

Okada H, Bukry D. 1980. Supplementary modification and introduction of code numbers to the low-latitude coccolith biostratigraphic zonation (Bukry 1973, 1975). Mar. Micropaleontol. 5: 321-325.

Pérez-Venzor JA, Carreño AL. 1995. Descripción litológica de algunos afloramientos de rocas del área de Las Pocitas, Baja 
California Sur. In: Resúmenes. Tercera Reunión Internacional sobre Geología de la Península de Baja California, México. Universidad Autónoma de Baja California Sur, 212 pp.

Perrilliat MC. 1996. Occurrence of the Tethyan gastropods Campanile and Gisortia in the lower Eocene part of the Tepetate Formation, Baja California Sur, Mexico. Veliger 39: 178-183.

Premoli-Silva I, Rettori R, Verga D. 2003. Practical Manual of Paleocene and Eocene Planktonic Foraminifera. In: Rettori R, Verga D (eds.), International School on Planktonic Foraminifera, 2o course: Paleocene and Eocene, Perugia 17-21 February, 2003. Dipartimento di Scienze della Terra, Univerity of Perugia, Italy, $152 \mathrm{pp}$.

Postuma JA. 1971. Manual of Planktonic Foraminifera. Elsevier, Amsterdan, 420 pp.

Smith PB. 1964. Ecology of benthonic species: Recent foraminifera off Central America. US Geol. Surv. Prof. Pap. 429B, 55 pp.

Stainforth RM, Lamb JL, Luterbacher H, Beard JH, Jeffords RM. 1975. Cenozoic planktonic foraminiferal zonation and characteristics of index forms. Univ. Kansas Paleontol. Contrib. 62: 1-425.

Steineck PL, Gibson JM. 1971. Age and correlation of the Eocene Ulatisian and Narizian stages, California. Bull. Geol. Soc. Am. 82: $47-480$.
Steineck PL, Gibson JM, Morin RW. 1972. Foraminifera from the Middle Eocene Rose Canyon and Poway formations, San Diego, California. J. Foraminifer. Res. 2: 137-142.

Toumarkine M, Luterbacher HP. 1985. Paleocene and Eocene planktonic foraminifera. In: Bolli HM, Saunders JB, PerchNielsen K (eds.), Plankton Stratigraphy. Cambridge Earth Science Series, pp. 87-154.

Vázquez-García A. 1996. Litología y ambientes de depósito de la formación Tepetate en el arroyo El Conejo, Baja California Sur. Tesis de licenciatura inédita, Departamento de Geología Marina, Universidad Autónoma de Baja California Sur, 72 pp.

Vázquez-García A, Schwennicke T. 1996. Paleochannels formed by bypass tempesites of the Tepetate Formation at Arroyo El Conejo and Aguajito, Baja California Sur, Mexico. In: Resúmenes. XIII Convención Geológica Nacional, México, Universidad Autónoma de Baja California Sur, p. 59.

Zachos JC, Pagani M, Sloan L, Thomas E. Billups K. 2001. Trends, rhythms, and aberrations in global climate 65 Ma to present. Science 292: 686-693.

Recibido en septiembre de 2007; aceptado en abril de 2008. 
Appendix. Cheklist of foraminifers recorded in Las Pocitas core.

Apéndice. Listado de los foraminíferos identificados en el núcleo Las Pocitas.

Acarinina aquiensis Loeblich and Tappan 1957. IGM-845-Mi.

Acarinina bullbrooki Bolli 1957. IGM-846-Mi.

Acarinina cf. crassata var. densa Cushman 1925. IGM-847-Mi.

Acarinina collactea (Finlay 1939) Jenkins. IGM-848-Mi.

Acarinina crassata var. densa Cushman 1925. IGM-849-Mi.

Acarinina decepta Martin 1943. IGM-850-Mi.

Acarinina esnaensis Le Roy 1953. IGM-851-Mi.

Acarinina marksi Martin 1943. IGM-852-Mi.

Acarinina matthewsae Blow 1979. IGM-853-Mi.

Acarinina pentacamerata (Subbotina 1947) Subbotina. IGM-854-Mi.

Acarinina primitiva Finlay 1947. IGM-855-Mi.

Acarinina pseudotopilensis Subbotina 1953. IGM-856-Mi.

Acarinina spinuloinflata Bandy 1949. IGM-857-Mi.

Acarinina tribulosa Bolli 1957. IGM-858-Mi.

Alabamina wilcoxensis var. californica Mallory 1959. IGM-859-Mi.

Angulogerina wilcoxensis (Cushman and Ponton 1932) Cushman. IGM-860-Mi.

Anomalinoides crassisepta Cushman and Siegfus 1935. IGM-861-Mi.

Anomalinoides judas Martin 1943. IGM-862-Mi.

Anomalinoides kennae Martin 1943. IGM-863-Mi.

Anomalinoides tennesseensis Berry and Cushman 1946. IGM-864-Mi.

Aragonia aragonensis (Nuttall 1930). IGM-865-Mi.

Assilina cushmani (Cole 1927) Loeblich and Tappan. IGM-866-Mi.

Asterigerina crassaformis Cushman and Siegfus 1936. IGM-867-Mi.

Bolivina alazanensis Cushman 1927. IGM-868-Mi.

Bolivina midwayensis Cushman 1937. IGM-869-Mi.

Bolivina pisciformis Galloway and Morrey 1929. IGM-870-Mi.

Bulimina consanguinea Parker and Bermúdez 1937. IGM-871-Mi.

Bulimina alazanensis Cushman 1943. IGM-872-Mi.

Cibicides beatus Martin 1943. IGM-873-Mi.

Cibicides blanpiedi Toulmin 1941. IGM-874-Mi.

Cibicides coalingensis (Cushman and Hanna 1927) Laiming. IGM-875-Mi.

Cibicides eponidiformis Martin 1943. IGM-876-Mi.

Cibicides felix Martin 1943. IGM-877-Mi.

Cibicides fortunatus Martin 1943. IGM-878-Mi.

Cibicides kernensis Mallory 1959. IGM-879-Mi.

Cibicides martinezensis Cushman and Barksdale 1930. IGM-880-Mi.

Cibicides pseudowellorstorffi Cole 1927. IGM-881-Mi.

Cibicides whitei Martin 1943. IGM-882-Mi.

Cibicidina mauriscensis Howe and Roberts 1939. IGM-883-Mi.

Cibicidoides pseudoungerianus Cushman 1922. IGM-884-Mi.

Cyclammina clarki Hanna 1923. IGM-885-Mi.

Dentalinoides colei Cushman and Dusenbury 1934. IGM-886-Mi.

Dentalinoides communis (d’Orbigny 1840) Beck. IGM-887-Mi.

Dentalinoides consobrina (d'Orbigny 1846) Cushman and Hanna. IGM-888-Mi.

Dentalinoides jacksonensis (Cushman and Applin 1926) Cushman. IGM-889-Mi.

Discorbis cocoaensis Cushman and Garrett 1938. IGM-890-Mi.

Dorothia colei Cushman and Siegfus 1935. IGM-891-Mi.

Dorothia principiensis Cushman and Bermúdez 1936. IGM-892-Mi.

Epistomina partschiana (d’Orbigny 1826). IGM-893-Mi.

Eponides lodoensis Martin 1943. IGM-894-Mi. 
(Continued)

Eponides mexicana (Cushman 1925) Cushman. IGM-895-Mi.

Eponides minima Cushman 1933. IGM-896-Mi.

Eponides primus Martin 1943. IGM-897-Mi .

Fissurina crassicarinata Bandy 1949. IGM-898-Mi .

Fissurina orbignyana (Seguenza 1862) Kelley. IGM-899-Mi.

Frondicularia tenuissima Hantken 1875. IGM-900-Mi .

Fursenkoina dibollensis Cushman and Applin 1926. IGM-901-Mi.

Gaudryna convexa Cushman sandiegensis Cushman and Hanna 1927. IGM-902-Mi.

Gaudryna jacksonensis Cushman var. coalingensis Cushman and Hanna 1927. IGM-903-Mi .

Gaudryna modica Bermúdez 1949. IGM-904-Mi.

Glandulina conica (Neugeboren 1926) Cushman and Barksdale. IGM-905-Mi.

Glandulina ovata (d’Orbigny 1864) Cushman and Applin. IGM-906-Mi.

Globanomalina champmani (Parr 1938) Bolli. IGM-907-Mi.

Globanomalina planoconica (Subbotina 1953) Bolli. IGM-908-Mi.

Globigerinatheka senni Beckmann 1953. IGM-909-Mi.

Globobulima pacifica (Cushman 1927) Cushman 1943. IGM-910-Mi.

Globocassidulina globosa Hantken 1875. IGM-911-Mi.

Grigelis kressenbergensis (Gümbel 1929) Smith. IGM-912-Mi.

Guembelitrioides lozanoi Colom 1954. IGM-913-Mi.

Gyroidinoides soldanii d’Orbigny var. octocamerata Cushman and Hanna 1927. IGM-914-Mi.

Hemirobulina glabra (d’Orbigny 1864) Plummer 1926. IGM-915-Mi.

Hemirobulina subbullata Hantken 1875. IGM-916-Mi.

Igorina broedermanni (Cushman and Bermúdez 1949) Bolli. IGM-917-Mi.

Karreriella lodoensis Israelsky 1951. IGM-918-Mi.

Lagena acuticosta Reuss 1862. IGM-919-Mi.

Lagena aspera Galloway and Morrey 1929. IGM-920-Mi.

Lagena costata (Williamson 1858) Cushman. IGM-921-Mi.

Lagena gracilicosta (Reuss 1863) Cushman. IGM-922-Mi.

Lagena laevis (Montaug) stavensis Bandy 1949. IGM-923-Mi.

Lagena striata (d’Orbigny 1839) Cushman. IGM-924-Mi.

Lenticulina alato-limbatus (Gümbel 1868). IGM-925-Mi.

Lenticulina alucinans Israelsky 1955. IGM-926-Mi.

Lenticulina antipodum (Stache 1865) Cushman and Dusenbury. IGM-927-Mi.

Lenticulina arcuato-striatus (Hantken 1875) Bermúdez. IGM-928-Mi.

Lenticulina coaledensis Detling 1946. IGM-929-Mi.

Lenticulina deformis (Reuss 1861) Galloway and Morrey. IGM-930-Mi.

Lenticulina limbosus (Reuss 1860) Cushman. IGM-931-Mi.

Lenticulina limbosus Reuss var. hockleyensis Cushman and Applin 1926. IGM-932-Mi.

Lenticulina macrodiscus Reuss 1861. IGM-933-Mi.

Lenticulina pseudocultratus Cole 1927. IGM-934-Mi.

Lenticulina pseudo-vortex Cole 1927. IGM-935-Mi.

Lenticulina theta Cole 1927. IGM-936-Mi.

Lenticulina vortex (Fichtel and Moll 1798) Israelsky. IGM-937-Mi.

Lenticulina weaveri Beck 1943. IGM-938-Mi .

Marginulinopsis curvatura Cushman 1946. IGM-939-Mi.

Morozovella aragonensis (Nuttall 1930) Bolli. IGM-940-Mi.

Morozovella caucasica (Glaessner 1937) McGowran. IGM-941-Mi.

Morozovella coronata Blow 1979. IGM-942-Mi.

Morozovella crassata (Cushman 1925) McGowran. IGM-943-Mi.

Morozovella hispidicidaris Martin 1943. IGM-945-Mi.

Morozovella spinulosa (Cushman 1927) Bolli. IGM-946-Mi .

Nodosaria arundinea (Schwager 1866) Cushman and Hanna. IGM-947-Mi. 
(Continued)

Nodosaria ewaldi Reuss 1845. IGM-948-Mi.

Nonion applini Howe and Wallace 1932. IGM-949-Mi.

Nonionella longicamerata Bandy 1949. IGM-950-Mi.

Patellina advena Rhumbler 1906. IGM-951-Mi.

Planorotalites palmerae Cushman and Bermúdez 1937. IGM-952-Mi.

Planorotalites pseudoscitula Glaessner 1937. IGM-953-Mi.

Planulina toddae Cushman 1944. IGM-954-Mi.

Planulina truncana (Gümbel 1868) Smith. IGM-970-Mi.

Pleurostomella alazanensis Cushman var. cubensis Cushman and Bermúdez 1937. IGM-983-Mi.

Pleurostomella clavata (Cushman 1926) Cushman and Renz. IGM-984-Mi.

Pleurostomella velascoensis Cushman 1926. IGM-1000-Mi.

Polymorphina austriaca (d’Orbigny 1864) Howe and Wallace. IGM-1007-Mi.

Praeglobobulimina pyrula (d’Orbigny 1826) Loeblich and Tappan. IGM-1008-Mi.

Pseudohastigerina wilcoxensis (Cushman and Ponton 1932) Bolli. IGM-1009-Mi.

Pullenia quinqueloba (Reuss 1851) Cushman and Todd. IGM-1010-Mi.

Pullenia reussi Cushman and Todd 1943. IGM-1011-Mi.

Pullenia salisburyi (Stewart and Stewart 1930) Beck. IGM-1012-Mi.

Pyramidulina latejugata (Gümbel 1868) Cushman and Renz. IGM-1013-Mi.

Quinqueloculina josephina (d'Orbigny 1846) Cushman and Hanna. IGM-1014-Mi.

Quinqueloculina yeguaensis Weinzierl and Applin 1929. IGM-1016-Mi.

Ramulina aff. $R$. navarroana Cushman 1926. IGM-1017-Mi.

Saracenaria triangularis (d’Orbigny 1840) Cushman. IGM-1018-Mi.

Siphonina advena Cushman 1922. IGM-1022-Mi.

Siphonina jacksonensis Cushman 1927. IGM-1026-Mi.

Siphonina wilcoxensis Cushman 1927. IGM-1027-Mi.

Siphonodosaria cocoaensis (Cushman 1925) Cushman. IGM-1028-Mi.

Spirillina vivipara (Ehrenberg 1843) Brady. IGM-1029-Mi.

Spiroloculina lamposa Hussey 1949. IGM-1030-Mi.

Spiroplectammina eocenica Cushman and Barksdale 1930. IGM-1031-Mi.

Spiroplectammina richardi Martin 1943. IGM-1032-Mi.

Spiroplectammina tejonensis Mallory 1959. IGM-1033-Mi.

Subbotina eocaena (Guembel 1868) Bolli. IGM-1034-Mi.

Subbotina frontosa (Subbotina 1947) Bolli. IGM-1035-Mi.

Subbotina hagni Gohrbandt 1967. IGM-1036-Mi.

Subbotina inaequispira Subbotina 1953. IGM-1037-Mi.

Subbotina linaperta (Finlay 1957) Bolli. IGM-1038-Mi.

Trifarina advena Cushman var. californica Mallory 1959. IGM-1039-Mi.

Tritaxilina colei Cushman and Siegfus 1935. IGM-1040-Mi.

Uvigerina lodoensis Martin var. miriamae Mallory 1959. IGM-1041-Mi.

Uvigerina wilcoxensis Cushman and Garrett 1939. IGM-1042-Mi.

Uvigerina yazooensis Cushman 1933. IGM-1043-Mi.

Vaginulinopsis mexicana (Cushman) var. alticostata Cushman and Barksdale 1930. IGM-1044-Mi.

Vaginulinopsis mexicana (Cushman) var. kerni Cook 1939. IGM-1045-Mi.

Vaginulinopsis mexicana (Cushman) var. nudicostata Cushman and Hanna 1927. IGM-1048-Mi.

Vaginulinopsis mexicana (Cushman) var. vacavillensis Hanna 1923. IGM-1049-Mi.

Valvulineria jacksonensis Cushman 1933. IGM-1050-Mi.

Verneuilina aff. triangulata Cook 1939. IGM-1051-Mi.

Verneuilina triangulata Cook 1939. IGM-1052-Mi.

Vulvulina curta Cushman and Siegfus 1935. IGM-1053-Mi. 